\title{
Ecosystem Service Value for the Common Reed Wetlands in the Liaohe Delta, Northeast China
}

\author{
Siyuan Ye' ${ }^{1}$ Edward A. Laws ${ }^{2 *}$, Robert Costanza ${ }^{3}$, Hans Brix ${ }^{4}$ \\ ${ }^{1}$ Key Laboratory of Coastal Wetland Biogeosciences, China Geological Survey, Qingdao Institute of Marine \\ Geology, CGS, Ministry of Land and Resources, Qingdao, China \\ ${ }^{2}$ Department of Environmental Sciences, School of the Coast and Environment, Louisiana State University, \\ Baton Rouge, USA \\ ${ }^{3}$ Crawford School of Public Policy, The Australian National University, Canberra, Australia \\ ${ }^{4}$ Department of Bioscience, Aarhus University, Aarhus, Denmark \\ Email: siyuanye@hotmail.com, *edlaws@lsu.edu,rcostanz@gmail.com
}

Received 11 October 2015; accepted 15 February 2016; published 18 February 2016

Copyright (C) 2016 by authors and Scientific Research Publishing Inc.

This work is licensed under the Creative Commons Attribution International License (CC BY).

http://creativecommons.org/licenses/by/4.0/

(c) (i) Open Access

\section{Abstract}

The largest reed field in the world, with an area of $1000 \mathrm{~km}^{2}$ in 1953, is located in the Liaohe Delta, which lies in the five-point-in-a-line economic strategic zone of northeastern China. However, the area of reeds has declined dramatically in recent years to accommodate oil field infrastructure and societal developments. Although the direct and indirect services provided by such wetlands make valuable contributions to human welfare, wetlands are often given little weight in policy decisions, because ecosystem services are not fully "captured" in commercial markets or adequately quantified in terms comparable with the values of economic services and manufactured capital. In this study the value of 10 of 17 ecosystem services provided by the reed wetlands in the Liaohe Delta was estimated by using market pricing, shadow projects, and benefit transfer methods. The value of the 10 services provided by the $800 \mathrm{~km}^{2}$ of reed wetland totaled approximately US $\$ 2.68$ billion. Remarkably, aquaculture and the production of pulp from reeds accounted for only $19 \%$ of the total value of the reed wetland services. About $32 \%$ of the value of the ecosystem services was attributed to non-consumptive recreation, an easily perceived service that may act as a powerful incentive for sustainable management of this wetland ecosystem. The results of this study should help not only to guide management decisions with respect to this particular wetland but also to serve as an example of the approach to be taken with respect to valuation of similarly endangered wetlands throughout China.

\footnotetext{
${ }^{*}$ Corresponding author.
} 
Keywords

China, Common Reeds, Ecosystem Services, Liaohe Delta, Valuation

\section{Introduction}

In China, water is a scarce resource. Compared to other countries on a per capita basis, China receives about $53 \%$ as much precipitation as India, $21 \%$ as much as the United States, and $15 \%$ as much as Russia. The amount of freshwater per person is only $25 \%$ of the world average [1]. The small amount of precipitation is particularly troublesome in the heavily populated but semi-arid northeastern region of the country, a transition zone that has been likened to the West African Sahel. Northern China has only about 20\% of the per capita water supply of southern China [1] and since 1950 precipitation in that region has averaged only about $355 \mathrm{~mm} \cdot \mathrm{y}^{-1}$ [2]. Use of groundwater for irrigation in northern China has resulted in the over drafting of aquifers, the result being a steady lowering of the water table. Wada et al. [3] estimate that about $15 \%$ of the water used to irrigate crops in China is accounted for by non-sustainable over drafting of aquifers. Furthermore, discharges of untreated or inadequately treated wastewater have seriously impacted the quality of many streams and lakes in China [4]-[6], and as a result the ability of many of these freshwater systems to provide much-needed ecosystem services has been seriously compromised.

Wetlands have the potential to mitigate problems associated with both the supply and quality of freshwater. First, wetlands store and subsequently release water that would otherwise be rapidly discharged to streams [7]. Second, wetlands remove contaminants from polluted water through natural processes, and indeed many constructed wetlands have been used to treat wastewater prior to release or reuse [8]-[11]. However, despite their potential to help China address its water supply and water quality problems, China's wetlands are collectively an endangered habitat; agricultural development and urbanization are the principal threats [12] [13].

The Liaohe Delta (LHD) in northeastern China is the site of perhaps the largest common reed (Phragmites australis, hereafter Phragmites) wetland in the world [14] [15]. The delta has a total area of about $5000 \mathrm{~km}^{2}$, and as recently as 1953 more than $1000 \mathrm{~km}^{2}$ was covered by Phragmites. The area of reeds decreased dramatically during the subsequent quarter century as a result of expansion of agricultural activities and oil field development. However, cultivation of Phragmites as a source of raw material for the local paper industry reversed the pattern of loss beginning in the late 1980s, and by 2006 Phragmites covered an area of at least $913 \mathrm{~km}^{2}$ [16]. In recent years the area covered by Phragmites has fluctuated as a result of losses to agriculture and urbanization and gains from manual planting of reeds on fallow land. Current estimates indicate that the Phragmites wetland covers about $800 \mathrm{~km}^{2}$.

The loss of roughly $100 \mathrm{~km}^{2}$ of reed wetland since 2006 reflects to some extent the absence of an informed assessment of the value of the wetland to guide managerial decisions, for as noted by Liu et al. ([17], p. 54), "It is impossible to manage what we do not value". The present study was therefore undertaken to estimate the value of the ecosystem services provided by the Phragmites wetland in the Liaohe Delta. The expectation is that this valuation will help not only to guide management decisions with respect to this particular wetland, but also to serve as an example of the approach to be taken with respect to valuation of similarly endangered wetlands throughout China.

\section{Materials and Methods}

\subsection{Study Site}

The study site is located in northeastern China in the LHD (121 $\left.10^{\prime}-122^{\circ} 30^{\prime} \mathrm{E}, 40^{\circ} 30^{\prime}-41^{\circ} 30^{\prime} \mathrm{N}\right)$ (Figure 1), which has been formed by sediments deposited by the Liaohe River, Daling River, Xiaoling River, and Daqing River. Of these rivers, the Liaohe River is the largest, with a total length of $1396 \mathrm{~km}$ and a drainage area of 2.19 $\times 10^{5} \mathrm{~km}^{2}$ (the Liaohe River was previously named the Shuangtaizi River, but the name was changed to Liaohe River in early March of 2011). The Delta has a total area of about $5000 \mathrm{~km}^{2}$, of which about $1000 \mathrm{~km}^{2}$ was historically covered by Phragmites [18]. The climate of the LHD is relatively moist and cool compared to the Yellow River Delta. The temperature ranges from $-24.8^{\circ} \mathrm{C}$ to $35.2^{\circ} \mathrm{C}$, with an annual average of $8.4^{\circ} \mathrm{C}$. The annual 


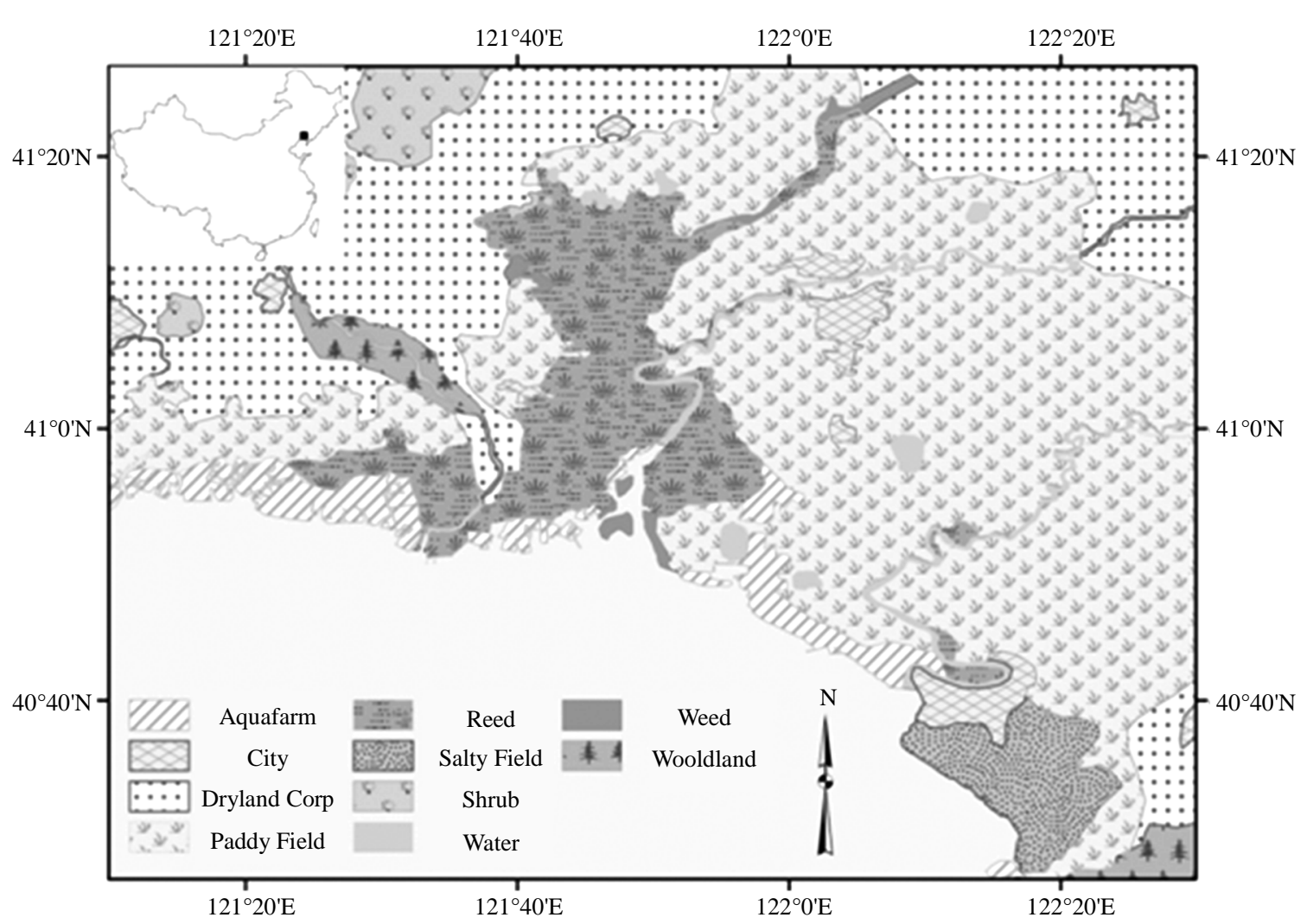

Figure 1. Distribution of land use in the Liaohe Delta in 2009.

precipitation and evaporation are $623.2 \mathrm{~mm}$ and $1669 \mathrm{~mm}$, respectively [19].

The wetlands in the LHD are of great importance from the standpoint of biodiversity because a large number of species, including some that are rare and endangered, live and breed in the wetlands or use the wetlands as a resting and feeding place during migrations [20]. Statistics indicate that there are 411 species of 124 families of vertebrates, including the red-crowned crane (Grus japonensis), white-naped crane (Grus vipio), and Chinese black-headed gull (Chroicocephalus saundersi). The wetland of the LHD, therefore, were designated as a Shuangtaizikekou (Liaohekou) national Nature Reserve since 1986 and also listed as a Ramsar site since 2004 [21].

\subsection{Background}

For more than 50 years, the work of the Panjin Wetland Science Research Institute (PWSRI) in Panjin City, Liaoning province has been centered around understanding the ecology of the coastal wetland ecosystems in the LHD, with the aim of developing a comprehensive plan for utilization of the wetland resources, while at the same time protecting the wetland environment and the many ecosystem services provided by the wetlands. To update the articulation of that mission, a workshop attended by PWSRI scientists was held in May 2012. The goal of the workshop was to assess the value of the wetland ecosystem, with a special focus on the value of the Phragmites wetlands for biomass utilization by the paper industry. The philosophy behind the research and management scheme developed and practiced at the PWSRI has been that optimization of possible economic opportunities for exploiting the coastal wetland resources in an environmentally friendly manner is the best way to protect the coastal wetlands of China. Papermaking from reed biomass is therefore considered a valuable economic product of the ecosystem services provided by the wetlands and an incentive for the creation, restoration, and protection of wetlands. A second workshop on 7 August 2013 included Dr. Haifeng Jia (Tsinghua University), an expert on the use of wetlands for wastewater treatment, who provided input on the value of wetland services with respect to wastewater treatment based on current market prices.

Information presented at the above two workshops revealed that the reed wetland ecosystem provided many essential goods and services that contribute to human welfare. Ecosystem service valuation is an assessment of 
the value of natural capital and involves a conservative estimate of the value of natural ecosystem services based on current available knowledge. Over the past decade, progress has been made in understanding how ecosystems provide services and how service provision translates into economic value [23]-[28]. The classification of the ecosystem services provided by the LHD wetlands was based on Costanza et al. [29], who grouped ecosystem services into 17 major categories that included renewable services but excluded atmospheric services and services associated with non-renewable fuels and minerals.

\subsection{Data Collection and Evaluation Methods}

Ecosystem services provide the benefits that people derive directly or indirectly from ecosystems. Ecosystem service valuation is the process of assessing the contributions of ecosystem services to sustainable human wellbeing [29]. There are various methods for estimating both the market and non-market components of the value of ecosystem services [30]. In this study, we used three valuation methods: 1) For those ecosystem services can be traded in commercial markets or adequately quantified in terms comparable with economic services and manufactured capital, the market-based valuation (MBV) was used to estimate marketable services based on current market prices and the collection of relevant statistics. The marketable ecosystem services considered in this study included gas regulation, wastewater treatment, food production, production of raw materials, and recreation that are "captured" in commercial markets. 2) Benefit value transfer (BVT) method was used because ecosystem services are not fully 'captured' in commercial markets or adequately quantified in terms comparable with economic services and manufactured capital, their services are estimated by utilizing existing valuation studies or data to estimate the value of ecosystem services in one location and transfer them to value ecosystem services in a similar location [29]. In this study, we applied the BVT method to assign values to ecosystem services that are not fully captured in current commercial markets, such as climate regulation, disturbance regulation, water regulation, water supply, and provision of habitat. The BVT method was used to valuate non-market components by using information from published valuation studies or relevant data to estimate the value of ecosystem services in one location and transfer that information to valuate ecosystem services in a similar location. 3) The shadow project approach (SPA) is a way of replacing primary ecosystem functions after the environment has been degraded [29]. That is the SPA was used to assess the value of an ecosystem service on the basis of how much it would cost to replace or restore the service if it were unavailable. In this study, the SPA was used to assess the value of papermaking by assuming that trees rather than reeds were the source of the pulp used to make paper.

The data collection was in 2012. In order to make the information from all studies comparable, all the presented results represented the statistical mean of individual estimates for each ecosystem service valuation and were expressed in 2012 USD per ha per year on the basis of consumer price index. And annual value (billion $\$ \mathrm{yr}^{-1}$ ) was obtained based on an area of $800 \mathrm{~km}^{2}$ of reed wetland in the LHD. Note that we included only renewable ecosystem services, excluding non-renewable fuels (such as oil field) and minerals and the atmosphere.

\section{Results}

We estimated the values of the following five kinds of services based on current market prices and local statistical data.

\subsection{Papermaking Service}

Wetlands are able to provide considerable quantities of a large array of raw materials for many purposes. In the case of the LHD, Phragmites is the raw material for pulp. The marginal value of the pulp produced from the reeds can reach 720 million Chinese Yuan, which was equivalent to US \$119 million in 2012. This estimate is based on annual pulp production of $1.8 \times 10^{8} \mathrm{~kg}$ from a reed biomass of $4.0 \times 10^{8} \mathrm{~kg}$ dry weight. The efficiency of conversion of reed biomass into pulp is therefore about $45 \%$, which is comparable to the efficiency with which wood is converted to pulp by the kraft process [31]. The net profit of pulp was 4 yuan $\cdot \mathrm{kg}^{-1}$ during the years 2010 and 2012. The areal value of the pulp produced by this reed wetland was therefore US $\$ 1475 \mathrm{ha}^{-1}$ in 2012 (Table 1).

If reeds were not used to provide the pulp for paper production, the alternative would be trees. Forests provide many valuable ecosystem services, and deforestation has been associated with very large environmental costs in 
Table 1. Annual value of ecosystem services in the Liaohe Delta. Inflation factors were assumed to be 1.55 from 1994 to 2012 and 1.12 from 2007 to 2012 [22].

\begin{tabular}{|c|c|c|c|c|c|c|}
\hline \multirow{2}{*}{ No } & \multirow{2}{*}{ Items } & \multirow{2}{*}{ Service } & \multirow{2}{*}{ References } & \multicolumn{3}{|c|}{ Converted a real value (US $\$ \mathrm{ha}^{-1} \cdot \mathrm{yr}^{-1}$} \\
\hline & & & & 1994 & 2007 & 2012 \\
\hline 1 & Gas Regulation & Carbon sequestration & This study & 177 & 245 & 274 \\
\hline 2 & Climate regulation & Sparing forests & This study & 1377 & 1905 & 2134 \\
\hline \multirow[t]{2}{*}{3} & Disturbance Regulation & Shoreline protection/erosion control & In de Groot et al. [28] & 1617 & 2238 & 2507 \\
\hline & Tidal Marsh & Storm protection & & & & \\
\hline 4 & Water Regulation & Buffer for irrigation water for agriculture & In de Groot et al. [28] & 5155 & 7134 & 7990 \\
\hline 5 & Water Supply & Supply of groundwater in floodplain & In de Groot et al. [28] & 214 & 296 & 332 \\
\hline 6 & Erosion control & Root system can fix sediments & & & & \\
\hline 7 & Soil formation & Add C, N, and P to the soil & & & & \\
\hline 8 & Nutrient cycling & Absorb and recycle large amounts of nutri & ients & & & \\
\hline 9 & Waste Treatment & Total $($ org $+\mathrm{N}+\mathrm{P})$ & & & & \\
\hline 10 & Pollination & Pollination function of certain wetland spe & ecies & & & \\
\hline 11 & Biological control & Pest control & & & & \\
\hline 12 & Habitat/Refugia & Fish + shrimp & In de Groot et al. [28] & 814 & 1127 & 1262 \\
\hline \multirow[t]{2}{*}{13} & Food Production & Aquaculture & This study & 3174 & 4393 & 4920 \\
\hline & & Soft drinks made from reed roots & & & & \\
\hline 14 & Raw Materials & Biomass, pulp & This study & 952 & 1317 & 1475 \\
\hline 15 & Genetic resources & Provide a habitat for species & In de Groot et al. [28] & 1311 & 1815 & 2033 \\
\hline 16 & Recreation & Tourism & This study & 6821 & 9440 & 10573 \\
\hline \multirow[t]{4}{*}{17} & Culture & Aesthetic value & & & & \\
\hline & & Pictures made from reeds & & & & \\
\hline & Total value US $\$ \mathrm{ha}^{-1} \cdot \mathrm{y}^{-1}$ & & & 21,612 & 29,910 & 33,499 \\
\hline & $\begin{array}{l}\text { Annual value (billion \$ yr } \\
\text { reed wetland }\end{array}$ & $\mathrm{r}^{-1}$ ) based on an area of $800 \mathrm{~km}^{2}$ of & & $\$ 1.73$ & $\$ 2.39$ & $\$ 2.68$ \\
\hline
\end{tabular}

China and elsewhere [1]. Use of reeds to provide the pulp for paper production spares ecologically valuable forests. We used SPA to take into consideration this facet of the ecosystem services provided by the reed wetland. For our calculations we used the biomass of a tropical rain forest, which we estimated to be 13.82 tonnes ha $^{-1}$. The annual harvest of $4.0 \times 10^{8} \mathrm{~kg}$ of reeds to produce pulp is therefore equivalent to harvesting about $2.9 \times 10^{4}$ ha of tropical rain forest for the same purpose. Therefore the equivalent of about $2.9 \times 10^{4}$ ha of tropical rain forests are spared each year by producing pulp from reeds rather than trees. The ecosystem services provided by tropical rain forests were valued at US $\$ 5264 \mathrm{ha}^{-1}$ in 2007 dollars by de Groot et al. [28]. This figure becomes US $\$ 5887 \mathrm{ha}^{-1}$ in 2012 after correcting for inflation [22]. The SPA analysis therefore indicates that sparing trees by making paper from reeds is worth (US $\left.\$ 5887 \mathrm{ha}^{-1}\right) \times\left(2.9 \times 10^{4} \mathrm{ha}\right) /\left(8 \times 10^{4} \mathrm{ha}\right)=$ US $\$ 2134 \mathrm{ha}^{-1}$.

The job opportunities created from papermaking are also significant. For instance, the Zhenxing Ecological Papermaking Group of Liaoning employed $~ 1700$ persons in 2012, and because the city of Panjin plans to build another papermaking factory in the next year, more job opportunities are expected. The cultural value of this ecosystem service is considerable, but we lack adequate information to assign a number.

\subsection{Carbon Regulation}

Carbon (C) sequestration associated with annual above-ground biomass production of $4.0 \times 10^{5}$ tonnes dry weight of reeds equals $1.8 \times 10^{5}$ tonnes C. Measurements made in the summer of 2013 revealed that the ratio of 
below-ground biomass to above-ground biomass was $1.03 \pm 0.13$. Thus the total amount of carbon sequestered by the production of $4.0 \times 10^{5}$ tonnes of above-ground reed biomass is $3.7 \times 10^{5}$ tonnes $\mathrm{C}$, the equivalent of 1.3 $\times 10^{6}$ tonnes of $\mathrm{CO}_{2}$ fixed from the atmosphere annually. In this case we used MBV to estimate the value of carbon sequestration, and we based the market value of the carbon on what it would cost to sequester the carbon by growing trees, which we assumed to be US $\$ 60$ tonne $^{-1} \mathrm{C}$ [26]. The value of this ecosystem service is therefore $\left(3.7 \times 10^{5}\right.$ tonnes C) $\left(\mathrm{US} \$ 60\right.$ tonne $\left.^{-1} \mathrm{C}\right) /\left(8 \times 10^{4} \mathrm{ha}\right)=\mathrm{US} \$ 274 \mathrm{ha}^{-1} \cdot \mathrm{y}^{-1}$ (Table 1$)$.

\subsection{Food Production}

The major fishery resource associated with the reed wetland in the LHD is crab. The marginal value of the reed wetland with respect to crabs is 2000 yuan per mu $(1 \mathrm{mu}=0.0667 \mathrm{ha})$. The areal value was therefore about $\left(2000\right.$ yuan $\left.\cdot \mathrm{mu}^{-1}\right) /\left(0.0667 \mathrm{ha} \cdot \mathrm{mu}^{-1}\right) /\left(6.1\right.$ yuan/US $\left.\${ }^{-1}\right)=$ US $\$ 4920 \mathrm{ha}^{-1} \cdot \mathrm{y}^{-1}$ in 2012 dollars (Table 1$)$.

\subsection{Recreation}

Recreational benefits from the wetlands are very large in the LHD. An extensive system of boardwalks has been constructed to provide access for tourists (Figure 2), who come primarily for sightseeing and bird watching. The tourist-associated income to the city of Panjin includes the price of tickets for access to the system of boardwalks and the income to hotels and restaurants. We based our estimate of the value of tourism on the number of persons who purchased boardwalk tickets in 2012 and the cost of food and lodging at local hotels. The total annual recreation-associated income amounted to 5.16 billion Chinese yuan or US $\$ 10,573 \mathrm{ha}^{-1}$ in 2012 (Table 1).

\subsection{Wastewater Treatment}

Wetlands can break down and transform much of the organic matter in wastewater, and they can remove nutrients through harvesting of biomass and, in the case of nitrogen, via denitrification. These services can be provided without negative side effects on the overall functioning of the ecosystem. After adjustment for inflation, the median value of wastewater treatment by wetlands summarized by de Groot [28] was US $\$ 4197 \mathrm{ha}^{-1} \cdot \mathrm{y}^{-1}$ in 2007. At the present time the only wastewater treated by the LHD reed wetland is the wastewater from the pulp mill. Because the cost of treating that wastewater is a cost associated with production of pulp from the reeds, we have not included the value of that service in our valuation of the reed wetlands. However, it is noteworthy that the wastewater produced by the mill is treated by the reed wetland and therefore does not impact the marginal value of the pulp.

\subsection{Other Services}

The values of several other important services provided by the wetland were estimated by BVT. These services included the following.

\subsubsection{Buffering of Supply of Irrigation Water for Rice Paddies}

Rice is a major agricultural crop in China and in the LHD. We estimated the value of this service in 2007 to be the median value cited by de Groot et al. [28] for coastal wetlands, US $\$ 7134 \mathrm{ha}^{-1} \cdot \mathrm{y}^{-1}$ (Table 1).

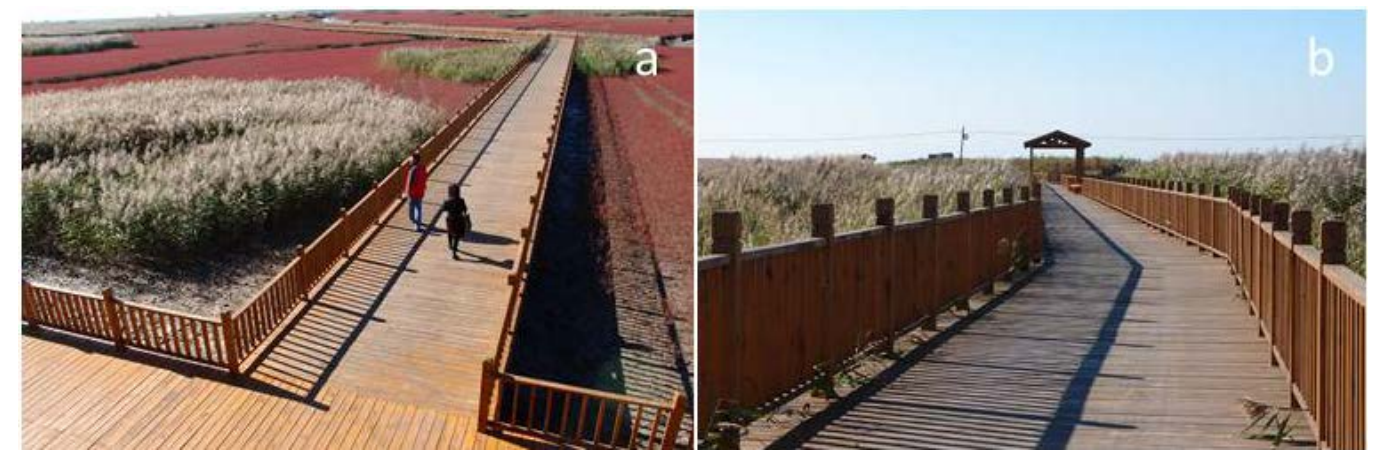

Figure 2. Boardwalks from tidal influent (a) to upper delta reed wetlands (b) in the Liaohe Delta were built in 2012. 


\subsubsection{Groundwater Supply}

The reed wetland lies in the floodplain of the upper delta and is therefore in a region ideal for groundwater recharge. Wetlands help to maintain the level of the water table and exert control on the hydraulic head. We estimated the value of this service in 2007 to be the median value cited by de Groot et al. [28] for coastal wetlands, US $\$ 296 \mathrm{ha}^{-1} \cdot \mathrm{y}^{-1}$ (Table 1 ).

\subsubsection{Habitat Refugia}

The wetlands of the LHD provide a habitat for a large number of species, including some that are rare and endangered. Resident populations live and breed in the wetlands, and migratory birds use the wetlands as a resting and feeding place [20]. We estimated the value of this service in 2007 to be the median value cited by de Groot et al. [28] for coastal wetlands, US $\$ 1127 \mathrm{ha}^{-1} \cdot \mathrm{y}^{-1}$ (Table 1).

\subsubsection{Genetic Resources}

We estimated the value of this service in 2007 to be the median value cited by de Groot et al. [28] for coastal wetlands, US $\$ 1815 \mathrm{ha}^{-1} \cdot \mathrm{y}^{-1}$ (Table 1).

\section{Discussion}

Of the 17 major services provided by the reed wetland (Table 1), we were able to estimate the values of only 10 based on data collected during this study or from information in recent publications. Our estimate of the total value of the ecosystem services provided by this wetland is therefore conservative. Given this important caveat, we estimate the current value of the ecosystem services provided by this wetland to be about US $\$ 2.68$ billion $\cdot \mathrm{y}^{-1}$, assuming that the size of the wetland is maintained at $8 \times 10^{4}$ ha. The value of the 10 ecosystem services we were able to estimate, $\$ 33,499 \mathrm{ha}^{-1} \cdot \mathrm{y}^{-1}$, is about $80 \%$ larger (after correction for inflation) than the estimated value of coastal wetlands in northwestern Mexico [27]. The principal difference between the two estimates is the value of non-consumptive recreation, which we estimate to account for about $32 \%$ of the total value of the ecosystem services provided by the wetlands in the LHD. In the study of Camacho-Valdez et al. [27] the most valuable ecosystem services were flood control and water quality improvement.

Our estimated value of the LHD wetland ecosystem services in 1994, US $\$ 21,612 \mathrm{ha}^{-1} \cdot \mathrm{y}^{-1}$, is comparable to the value of estuaries (US $\$ 22,832 \mathrm{ha}^{-1} \cdot \mathrm{y}^{-1}$ ) in Costanza et al. [29] and greater than the value of the other biomes included in that study. Remarkably, the values associated with papermaking and commercial fishing (Table 1) accounted for only $19 \%$ of the total value of the ecosystem services. The importance of recreation, however, could act as a powerful incentive to conserve this ecosystem. The total value of the ecosystem services is almost certainly much larger than our estimate, because we assigned no value to seven services, namely erosion control, soil formation, nutrient cycling, waste treatment, pollination, biological control, and culture.

The implication of this valuation is that the ecosystem services of the LHD reed wetland provide an important portion of the total contribution to human welfare in the LHD. The goal of this study was to provide a quantitative basis for giving the stock of natural capital that produces these services adequate weight in policy decisions. Otherwise the area of the reed wetland may further decline. An important use of this valuation will be the costbenefit analysis of proposed projects. In such analyses "ecosystem services lost must be weighed against the benefits of a specific project. Because ecosystem services are largely outside the market and uncertain, they are too often ignored or undervalued, leading to the error of constructing projects whose societal costs far outweigh their benefits".

There are, of course, uncertainties involved in ecosystem service valuation. This is especially true in the case of the value transfer method, which assumes that values are independent of the type of ecosystem. This assumption can lead to errors, because there are fundamental differences between ecosystems and the populations that the services benefit. Given the uncertainties involved, the valuation of ecosystem services may never be very precise. Nevertheless, even a crude initial estimate can be a useful starting point. This calculation also addresses the relative importance of ecosystem services and the potential impact of alternative uses of the land on the welfare of local people.

The wetlands of China cover an estimated $2.3 \times 10^{7}$ ha, about $2.7 \%$ of the area of China. Those wetlands include $1.2 \times 10^{7}$ ha of marshes and bogs, $9.1 \times 10^{6}$ ha of lakes, and $2.2 \times 10^{6}$ ha of coastal salt marshes and mud flats [32]. About $95 \%$ of the population of China lives in the eastern half of the country, where large areas of 
wetlands have been drained for agriculture and urban development, or converted to rice paddies, aquaculture ponds, or water-storage reservoirs. Between 1960 and 2000 China lost almost $2.2 \times 10^{6}$ ha of intertidal wetlands to reclamation and urban and industrial encroachment [32]. Most of China's remaining coastal marshes and mudflats occur in the deltas of the Yellow River and Liaohe River.

The continued loss of these and other wetlands would be tragic. Fortunately there is increasing awareness of the important role of floodplain wetlands in water storage and flood control and the role of mangrove swamps in fisheries production and coastal protection. This valuation of the ecosystem services provided by the wetlands of the LHD has been an important first step in the quantification of the value of these and similar wetlands to the people of China. Although there are moral and aesthetic reasons for protecting wetlands, such reasons are likely to have little influence on decision makers who are pursuing strictly economic goals. It has therefore become essential in policy and decision-making to consider the economic benefits humans derive from well-functioning ecosystems. The concept of ecosystem services has been developed to address this link between ecosystems and human welfare [33]. Because policy decisions are often evaluated through cost-benefit assessments, an economic analysis can help make ecosystem service research operational.

\section{Conclusion}

We have estimated the value of 10 ecosystem services provided by the wetlands of the LHD. Five of those services - carbon sequestration, the sparing of forests, food production, papermaking, and recreational value-were original valuations based on current market prices. The remaining five services-shoreline protection/erosion control, buffer for irrigation water, water storage, genetic resources, and habitat/refugia — were estimated by using the value transfer method. Our analysis indicates that the Liaohe River wetlands provide ecosystem services worth at least US \$2.68 billion to the welfare of local people. Remarkably, the values associated with papermaking and commercial fishing accounted for only $19 \%$ of the total value of the ecosystem services. However, the $32 \%$ contribution from recreation is a readily perceived service that could act as a powerful incentive for sustainable management of this and similar ecosystems.

\section{Acknowledgements}

This study was jointly funded by Ministry of Land and Resources program: "Special foundation for scientific research on public causes” (Grant No. 201111023), National Natural Science Foundation of China (Grant Nos. 41240022 \& 40872167), Marine Safeguard Project (Grant No. GZH201200503), and the China Geological Survey (Grant No. 1212010611402).

\section{References}

[1] Diamond, J. (2005) Collapse: How Societies Choose to Fail or Succeed. Viking Penguin, New York.

[2] Gong, D.Y., Shi, P.J. and Wang, J.A. (2004) Daily Precipitation Changes in the Semi-Arid Region over Northern China. Journal of Arid Environments, 59, 771-784. http://dx.doi.org/10.1016/j.jaridenv.2004.02.006

[3] Wada, Y., van Beek, L.P.H. and Bierkens, M.F.P. (2012) Nonsustainable Groundwater Sustaining Irrigation: A Global Assessment. Water Resources Research, 48. http://dx.doi.org/10.1029/2011wr010562

[4] Xie, Y.X., Xiong, Z.Q., Xing, G.-X., et al. (2007) Assessment of Nitrogen Pollutant Sources in Surface Waters of Taihu Lake Region. Pedosphere, 17, 200-208. http://dx.doi.org/10.1016/S1002-0160(07)60026-5

[5] Guo, L. (2007) Doing Battles with Green Monster of Taihu Lake. Science, 317, 1166. http://dx.doi.org/10.1126/science.317.5842.1166

[6] Duan, H., Ma, R., Xu, X., et al. (2009) Two-Decade Reconstruction of Algal Blooms in China’s Lake Taihu. Environmental Science \& Technology, 43, 3522-3528. http://dx.doi.org/10.1021/es8031852

[7] Wright, R.T. and Boorse, D.F. (2013) Environmental Science. 12th Edition, Pearson, New York.

[8] Brix, H. (1994) Functions of Macrophytes in Constructed Wetlands. Water Science and Technology, 29, 71-78.

[9] Wu, H.M., Zhang, J.A., Li, P.Z., et al. (2011) Nutrient Removal in Constructed Microcosm Wetlands for Treating Polluted River Water in Northern China. Ecological Engineering, 37, 560-568. http://dx.doi.org/10.1016/j.ecoleng.2010.11.020

[10] Li, L.F., Li, Y.H., Biswas, D.K., et al. (2008) Potential of Constructed Wetlands in Treating the Eutrophic Water: Evidence from Taihu Lake of China. Bioresource Technology, 99, 1656-1663. 
http://dx.doi.org/10.1016/j.biortech.2007.04.001

[11] Ji, G.D., Sun, T., Zhou, Q.X., et al. (2002) Constructed Subsurface Flow Wetland for Treating Heavy Oil-Produced Water of the Liaohe Oilfield in China. Ecological Engineering, 18, 459-465. http://dx.doi.org/10.1016/S0925-8574(01)00106-9

[12] Zhang, J.Y., Ma, K.M. and Fu, B.J. (2010) Wetland Loss under the Impact of Agricultural Development in the Sanjiang Plain, NE China. Environmental Monitoring and Assessment, 166, 139-148. http://dx.doi.org/10.1007/s10661-009-0990-X

[13] Wang, M.J., Qi, S.Z. and Zhang, X.X. (2012) Wetland Loss and Degradation in the Yellow River Delta, Shandong Province of China. Environmental Earth Sciences, 67, 185-188. http://dx.doi.org/10.1007/s12665-011-1491-0

[14] Wang, X.L., Xiao, D.N., Bu, R.C., et al. (1997) Analysis on Landscape Patterns of the Liaohe Delta Wetland. Acta Ecologica Sinica, 17, 317-323.

[15] Wang, L., Li, X.Z. and Guo, D.F. (2003) Land Use Change and Consequences in the Liaohe Delta. Journal of Shandong Normal University (Natural Science), 18, 43-47.

[16] Ji, Y.H., Zhou, G.S., Lv, G.H., et al. (2009) Expansion of Phragmites australis in the Liaohe Delta, North-East China. Weed Research, 49, 613-620.

[17] Liu, S., Costanza, R., Farber, S., et al. (2010) Valuing Ecosystem Services Theory, Practice, and the Need for a Transdisciplinary Synthesis. In: Limburg, K. and Costanza, R., Eds., Ecological Economics Reviews, Wiley-Blackwell, Malden, 54-78.

[18] Brix, H., Ye, S., Laws, E.A., et al. (2014) Large-Scale Management of Common Reed, Phragmites australis, for Paper Production: A Case Study from the Liaohe Delta, China. Ecological Engineering, 73, 760-769. http://dx.doi.org/10.1016/j.ecoleng.2014.09.099

[19] Ye, S., Laws, E.A., Yuknis, N., et al. (2015) Carbon Sequestration and Soil Accretion in Coastal Wetland Communities of the Yellow River Delta and Liaohe Delta, China. Estuaries and Coasts, 38, 1885-1897. http://dx.doi.org/10.1007/s12237-014-9927-x

[20] Government Office of Panjin Chorography (1998) Panjin City Chorography (Agriculture Volume). Chorography Press, Beijing.

[21] Li, X.W., Liang, C. and Shi, J.B. (2012) Developing Wetland Restoration Scenarios and Modeling Its Ecological Consequences in the Liaohe River Delta Wetland, China. Clean-Soil Air Water, 40, 1185-1196. http://dx.doi.org/10.1016/j.ecoleng.2014.09.099

[22] US Bureau of Labor Statistics (2013) CPI Table by Year.

[23] Nelson, E., Mendoza, G., Regetz, J., et al. (2009) Modeling Multiple Ecosystem Services, Biodiversity Conservation, Commodity Production, and Tradeoffs at Landscape Scales. Frontiers in Ecology and the Environment, 7, 4-11. http://dx.doi.org/10.1890/080023

[24] Logsdon, R.A. and Chaubey, I. (2013) A Quantitative Approach to Evaluating Ecosystem Services. Ecological Modelling, 257, 57-65. http://dx.doi.org/10.1016/j.ecolmodel.2013.02.009

[25] Balmford, A., Bruner, A., Cooper, P., et al. (2002) Economic Reasons for Conserving Wild Nature. Science, 297, 950953. http://dx.doi.org/10.1126/science.1073947

[26] Stavins, R.N. (1999) The Costs of Carbon Sequestration: A Revealed-Preference Approach. American Economic Review, 89, 994-1009. http://dx.doi.org/10.1257/aer.89.4.994

[27] Camacho-Valdez, V., Ruiz-Luna, A., Ghermandi, A., et al. (2013) Valuation of Ecosystem Services Provided by Coastal Wetlands in Northwest Mexico. Ocean \& Coastal Management, 78, 1-11. http://dx.doi.org/10.1016/j.ocecoaman.2013.02.017

[28] de Groot, R., Brander, L., van der Ploeg, S., et al. (2012) Global Estimates of the Value of Ecosystems and Their Services in Monetary Units. Ecosystem Services, 1, 50-61. http://dx.doi.org/10.1016/j.ecoser.2012.07.005

[29] Costanza, R., D’Arge, R., de Groot, R., et al. (1997) The Value of the World's Ecosystem Services and Natural Capital. Nature (London), 387, 253-260. http://dx.doi.org/10.1038/387253a0

[30] Farber, S., Costanza, R., Childers, D.L., et al. (2006) Linking Ecology and Economics for Ecosystem Management. Bioscience, 56, 121-133. http://dx.doi.org/10.1641/0006-3568(2006)056\%5B0121:LEAEFE\%5D2.0.CO;2

[31] Huntley, S.K., Ellis, D., Gilbert, M., et al. (2003) Significant Increases in Pulping Efficiency in C4H-F5H-Transformed Poplars: Improved Chemical Savings and Reduced Environmental Toxins. Journal of Agricultural and Food Chemistry, 51, 6178-6183. http://dx.doi.org/10.1021/jf034320o

[32] Lu, X., Liu, H. and Yang, Q. (2000) Wetlands in China: Feature, Value and Protection. Chinese Geographical Science, 10, 296-301. http://dx.doi.org/10.1007/s11769-000-0043-4

[33] Fisher, B., Turner, K., Zylstra, M., et al. (2008) Ecosystem Services and Economic Theory: Integration for Policy Relevant Research. Ecological Applications, 18, 2050-2067. http://dx.doi.org/10.1890/07-1537.1 